\title{
FOREIGN TRADE IN IRON ORE IN EU COUNTRIES
}

\author{
Tomasz ROKICKI
}

Warsaw University of Life Sciences, Warsaw, Poland, EU, tomasz rokicki@sggw.pl

https://doi.org/10.37904/metal.2019.984

\begin{abstract}
The aim of this article is to present the relationship between the foreign trade in iron ore in European Union countries and the overall economic situation. The study covers the period from 2001 to 2017 . The sources of materials include literature, date from the EUROSTAT, World Steel Association and World Bank. The following methods have been used in this paper: descriptive, graphic and the Pearson linear correlation coefficient. The findings of the study indicate that steel use, production of industry sectors and Households consumption were generally most closely linked to changes in import of iron ore in the EU. The exceptions were GDP per capita, value of export, value of import, value of construction industry, prices of iron ore which did not indicate such a link. EU countries were net importers of iron ore. The only exceptions were the Netherlands and Sweden.
\end{abstract}

Keywords: Steel industry, iron ore, import, export, steel production, European Union

\section{INTRODUCTION}

Iron and steel, along with energy, were important raw materials needed to develop economies around the world. The situation in terms of demand, supply and foreign trade in this area has changed. For example, in England production grew rapidly in 1540 - 1620 and 1785 - 1810. Imports of iron from Spain declined sharply after 1540, but those from Sweden became significant from the mid - seventeenth century, and those from Russia after 1730. Countries used various sources of supply of metal raw materials [1-5].

In the mid-nineteenth century, Britain was the major supplier of iron and steel to the world market, while Germany and the United States were significant importers. In 1913, German exports exceeded British exports, and Great Britain became the main importer of steel. The export success of Britain in the mid-twentieth century was due to its superior technical efficiency and lower prices of raw materials. The fall of Britain as an exporter was due to a reversal of this favorable situation: after 1900, British industry was much less efficient than the German and American industries, and it worked under the burden of higher raw material prices [6-9].

Stocks of products in use are very important to lives of people. Demand for in-use stocks generates demand for metals. The study of in-use stocks has heretofore been widely neglected. For example, iron stocks in the United States over the period 1900-2004 increased to 3,200 Tg (million metric tons). In U.S. per-capita in-use iron stock reached saturation at 11-12 metric tons in 1980 [10]. Additionally, the United States became a net exporter of iron and steel in the mid-1890s. [11]. In general, industrialization in the developing world was connected with increased steel demand. For example, world production of iron ore increased from 274 million tons (Mt) in 1950 to $1554 \mathrm{Mt}$ in 2005, while steel production increased from 207 to $1259 \mathrm{Mt}$. The major iron ore producing countries are not the major steel producing countries and vice-versa. For example, in Brazil's steel production was approximately $10 \%$ of its iron ore production. Japan's steel production was very big, but this country had no domestic iron ore production $[12,13]$. Inventories per capita in countries with a long industrial history, e.g. in the USA, Great Britain or Germany, range from 11 to 16 tonnes, and the accumulation of stocks is slowing down or has come to a halt. Inventories in countries, that have recently become industrialized, such as Portugal, are between 6 and 10 tons per capita and are growing rapidly. In a few countries, stocks of steel per capita have saturated or are close to saturation [14,15]. In the world problem is management of resources of steel in the countries. In this case sustainability development is related to substance flows of steel stocks. Flows of iron ore are contrary to the idea of sustainable development $[16,17]$. 
In 2008, the Committee on Critical Mineral Impacts of the U.S. Economy, presented a definition of strategic raw materials, which was also adopted by European Union countries. The group of strategic raw materials includes 12 minerals / materials of very critical economic importance and special conditions related to the criticality and risk of supply shortage. The risk of shortage of supply results mainly from a limited number of sources of origin. These are: rhenium, tellurium, iron, aluminum, bauxite, magnesite, molybdenum, manganese, vanadium, zinc, nickel and chromium. Attention is drawn to raw materials used in large quantities in key industries (iron, aluminum) $[18,19]$

The global market for iron ore was dominated by China. In this country. In 2010, this country had reached a point at which it alone accounted for over $50 \%$ of the global trade of iron ore. Chinese increase demand for iron ore could not be satisfied by the production of the exporters. Exporters reduced their export to almost every other country such as the USA, Germany, and France who all have reduced their steel production. The prices have risen in consequences [20].

The main purpose of this paper is to determine the relationship between the foreign trade in iron ore in European Union countries and the overall economic situation. Specific aims were also set in the paper. These are: showing the directions of changes in steel consumption, identify the main exporters and importers of iron ore in the EU and illustration of the influence of the market and economic situation on foreign trade in iron ore in EU countries.

\section{METHODOLOGICAL BASES}

The period covered by the study is between 2001 and 2017, i.e. the years directly before the economic crisis, during the crisis, and the years of economic upturn. The sources of materials include literature, date from the EUROSTAT, World Steel Association and World Bank. The following methods have been used in this paper: descriptive, graphic and the Pearson linear correlation coefficient.

\section{RESULTS}

The largest steel demand in the EU was in Germany, followed by Italy, France, Poland and Spain. $25 \%$ of EU steel use was generated in Germany and as much as $65 \%$ in the five largest domestic consumer. In the years 2001-2017, apparent steel use (in crude steel equivalent) in EU countries decreased significantly (Figure 1). A significant decline in steel use was observed in 2009, during the onset of the economic crisis (a decrease by $37 \%$ ). After the economic crisis, there was usually a rapid return of steel consumption to the level from 2007-2008. The exceptions were Italy and France, which clearly reduced steel consumption in their economies.

Table 1 presents Apparent Steel Use per Capita (kilograms crude steel equivalent) in EU countries in 20012017. Data from the years 2001-2017 were divided into five periods, i.e. 2001-2004, 2005-2008, 2009, 20101013, 2014-2017. These were four four-year periods and one annual one for 2009 (when the economic crisis occurred). The analysis of steel consumption in the largest economies confirms that the decrease in consumption occurred only in 2009. That is why it was decided to separate this year. In general, steel consumption per capita in EU countries varied widely. The highest was definitely in the Czech Republic, then in Slovenia and Austria, i.e. in countries that were not in the lead of the countries consuming the biggest amount of steel in the EU. At the end of the ranking there were also countries with low total steel consumption. In turn, large economies ended up on further positions. The biggest increase of use steel per capita was recorded in Lithuania, Croatia, Slovak Republic, Czech Republic and Poland. However, these were countries with small total steel use. In turn, the biggest decreases were in Greece, Malta and Ireland, that is also in countries with small use volume. The period before the economic crisis, when steel use in most countries increased, was most favorable. As a consequence of the economic crisis, steel use fell in all countries. The exit from the crisis was an opportunity to restore steel use; however, in most countries there were decreases 
in use. This situation is affected by the relationships on the global market, and also economic relationships in the individual EU countries.

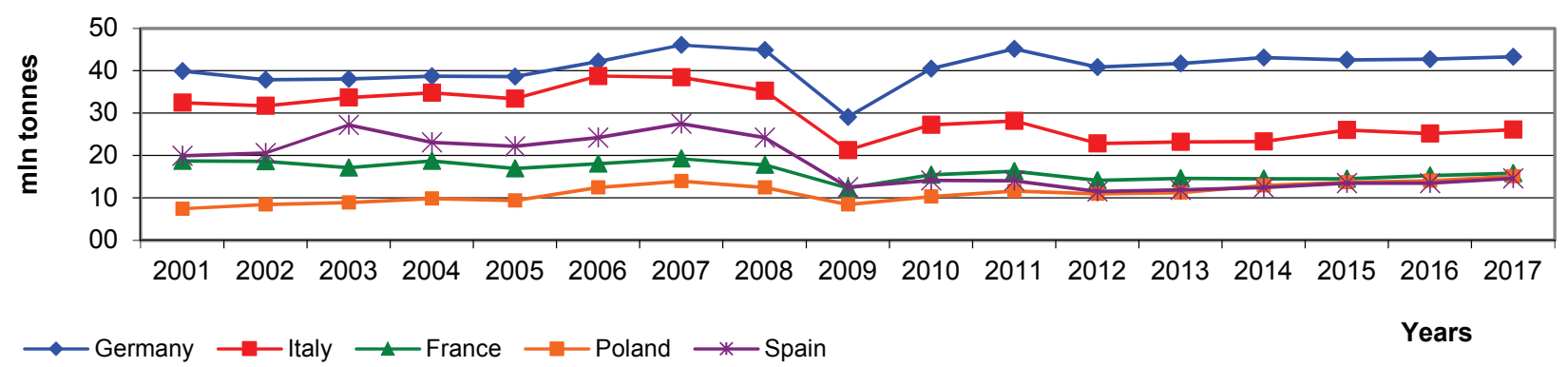

Figure 1 Top 5 EU countries in Apparent Steel Use (crude steel equivalent) in 2001-2017 [21,22]

Table 1 Top 5 EU countries in apparent Steel Use per Capita (kilograms crude steel equivalent) in EU countries in 2001-2017 [21,22]

\begin{tabular}{|l|c|c|c|c|c|}
\hline \multirow{2}{*}{ Countries } & \multicolumn{5}{c|}{ Apparent Steel Use per Capita (kilograms crude steel equivalent) in periods } \\
\cline { 2 - 6 } & $\mathbf{2 0 0 1 - 2 0 0 4}$ & $\mathbf{2 0 0 5 - 2 0 0 8}$ & $\mathbf{2 0 0 9}$ & $\mathbf{2 0 1 0 - 2 0 1 3}$ & $\mathbf{2 0 1 4 - 2 0 1 7}$ \\
\hline Czech Republic & 484 & 683 & 497 & 636 & 722 \\
\hline Slovenia & 569 & 657 & 470 & 505 & 522 \\
\hline Austria & 487 & 541 & 423 & 491 & 507 \\
\hline Germany & 469 & 523 & 359 & 519 & 525 \\
\hline Slovak Republic & 305 & 418 & 290 & 391 & 470 \\
\hline
\end{tabular}

Source: Own analyses based on data of EUROFER and World Steel Association.

The export of iron ore was rather rare in the European Union. Significant exporters include Sweden and the Netherlands. In other countries, the level of exports was very low. Sweden was a country that has historically always been an iron ore exporter. There was a slight increase in sales of this raw material. In the case of the Netherlands, there was a very large increase in iron ore exports. In large part, this was due to speculation and trade. The Netherlands was also a large importer of this raw material. During the economic crisis, declines in both countries were visible due to the lack of demand among customers.

The EU countries were definitely importers of iron ore. Large economies had the biggest needs, but imports occurred virtually in all EU countries. In the group of the largest importers of iron ore, there were countries that consumed the most steel (Figure 2). The exception was the Netherlands, but in its case a large part of the raw materials was resold for export. In all countries, there was a visible decline in purchases of iron ores in 2009. Particularly large declines occurred in the largest importers. Generally, after the crisis, the demand for steel and the import volume of iron ore were rebuilt very quickly. However, after the economic crisis in most countries, the level of imports was at a lower level than in the pre-crisis period. Imports only increased in the Netherlands (by $265 \%$ in 2001-2017), Sweden (57\%) and Slovakia (31\%). In other countries there were drops, the largest in Bulgaria (by $77 \%$ ), Italy (52\%), the United Kingdom (37\%), Belgium and Luxembourg (33\%), Romania (31\%).

The trading of iron ore could have been influenced by economic factors and prices of this raw material. The prices of iron ore in quotations on world markets were presented on a monthly basis in 2001-2017 (Figure 3). After the period of stabilization in the years 2001-2005, in the next period there was an increase in prices, especially rapid in 2007-2008. During the economic crisis, prices collapsed. In 2010, iron ore prices returned to the level of 2008. In the following years, a rapid drop in prices was visible, which lasted until 2016. The next year, 2017, was characterized by large increases and decreases in prices. Prices in international trade are the 
effect of the game of supply and demand. The demand reported by China, which dominates the market, has a significant impact on the market. As a result, iron ore producers are often unable to meet the needs of other countries. As a result, prices are rising. In the case of a large oversupply, prices are dropping.

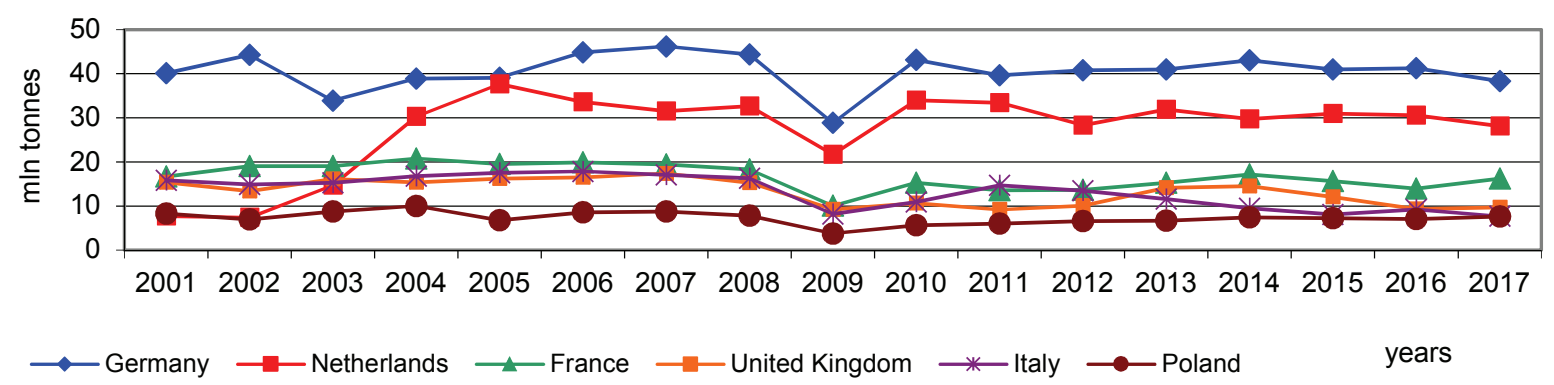

Figure 2 Main importers of Iron Ore in EU in 2001-2017 [21,22]

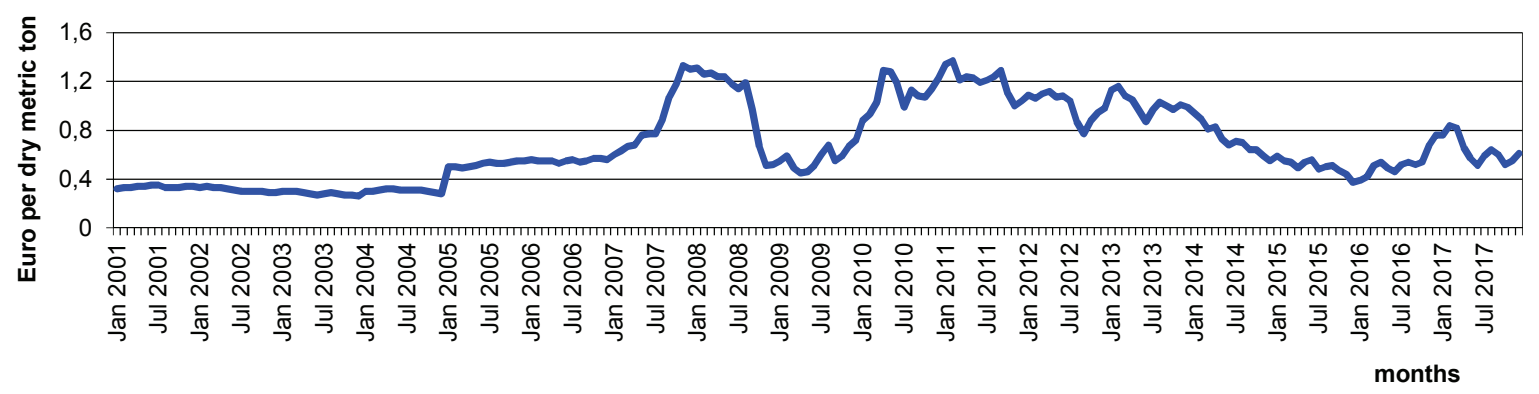

Figure 3 Global monthly prices of iron ore in 2001-2017 (Euro per dry metric ton) [23]

Table 2 Pearson correlation coefficients between export and import volume of iron ore in EU-countries and selected parameters [own study]

\begin{tabular}{|c|c|c|c|c|c|c|}
\hline \multirow[b]{2}{*}{ Parameters } & \multicolumn{6}{|c|}{ Pearson correlation coefficients in years } \\
\hline & $\begin{array}{l}2001- \\
2004\end{array}$ & $\begin{array}{l}2005- \\
2008\end{array}$ & 2009 & $\begin{array}{l}2010- \\
2013\end{array}$ & $\begin{array}{l}2014- \\
2017\end{array}$ & $\begin{array}{l}2001- \\
2017\end{array}$ \\
\hline \multicolumn{7}{|c|}{ The coefficients of correlation between iron ore import volume in EU countries and } \\
\hline Apparent Steel Use (crude steel equivalent) & 0.765 & 0.653 & 0.695 & 0.729 & 0.717 & 0.712 \\
\hline $\mathrm{p}$ value & 0.001 & 0.001 & 0.002 & 0.001 & 0.001 & 0.001 \\
\hline $\begin{array}{l}\text { Apparent Steel Use per Capita (kilograms crude } \\
\text { steel equivalent) }\end{array}$ & 0.155 & 0.007 & 0.153 & 0.258 & 0.140 & 0.155 \\
\hline $\mathrm{p}$ value & 0.207 & 0.965 & 0.558 & 0.034 & 0.255 & 0.008 \\
\hline GDP value & 0.392 & 0.276 & 0.281 & 0.228 & 0.217 & 0.261 \\
\hline$p$ value & 0.001 & 0.023 & 0.275 & 0.062 & .0 .076 & 0.001 \\
\hline Industry production & -0.184 & -0.287 & -0.291 & -0.264 & -0.276 & -0.231 \\
\hline$p$ value & 0.133 & 0.018 & 0.257 & 0.030 & 0.023 & 0.001 \\
\hline Households consumption & 0.398 & 0.292 & 0.302 & 0.257 & 0.256 & 0.286 \\
\hline $\mathrm{p}$ value & 0.001 & 0.016 & 0.239 & 0.034 & 0.035 & 0.001 \\
\hline
\end{tabular}

Pearson's linear correlation coefficient was used to determine the correlation between iron ore export and import volume in EU countries and selected measures of economic situation. Ten variables were selected on the basis of a review of literature, among others articles of [24,25]. The tests were carried out separately for the export 
and import of iron ore. Only six EU countries showed exports of this raw material. In the case of import, significant volume was demonstrated in 17 countries. Due to very low volumes of production, eleven countries were excluded from the analysis. Table 2 presents the results only for important parameters related to the export of iron ore, and shows the $p$-value. The significance threshold was set at $p=0.05$. Significant correlations were marked with grey background in the text. The correlation coefficients were calculated separately for the periods before, during and at the exit from the crisis, and for the entire period, i.e. the years 2001-2017.

In the case of the volume of iron ore exports from EU countries, all parameters were negligible. For iron ore exports, there was a very high positive correlation between the volume of steel consumption in a given economy and the level of iron ore imports. As a rule, the level of steel consumption per capita was irrelevant, except for 2010-2013 and 2001-2017, when there was a weak positive relationship. The weak positive relation was also in the case of dependence between the level of imports in EU countries and the value of GDP and the value of household consumption. A negative relationship was observed in the value of industry production. There was also a lack of dependence with regard to all parameters (except for steel consumption) in the year of the economic crisis. The following parameters were irrelevant: GDP per capita, value of export, value of import, value of construction industry, prices of iron ore.

For example, in UK imports of iron and steel are substantial, net imports are, in terms of both weight, a rather small part of total UK iron and steel production and use (just under $20 \%$ ) [26]. Wang et al. in their research had claimed, that in international trade of iron ore, iron and steel products, and scrap, most of countries are net iron importers (80 \%) [27]. In the early 1990s in western European countries most of primary zinc and other metals were imported as concentrate from North and South America and Oceania, and is smelted in Europe to refined metal [28]. A similar situation occurred in the case of copper ore flows. The majority of copper is mined outside of Europe. Countries of Europe were net importers [29,30].

\section{CONCLUSION}

Apparent Steel Use in the EU decreased in the years 2001-2017; nevertheless, these changes occurred with varying intensity in particular countries. In this period, there was an economic crisis, which additionally allowed for determining the regularities between economic situation and foreign trade in iron ore. Steel use, production of industry sectors and Households consumption were generally most closely linked to changes in import of iron ore in the EU. Interestingly, the study did not find any relationship between import of iron ore and GDP per capita, value of export, value of import, value of construction industry, prices of iron ore. In general, EU countries were net importers of iron ore. The only exceptions were the Netherlands and Sweden.

\section{REFERENCES}

[1] KING, P. The production and consumption of bar iron in early modern England and Wales. The Economic History Review, 2005, 58(1), pp. 1-33.

[2] FOUQUET, R., BROADBERRY, S. Seven Centuries of European Economic Growth and Decline. Journal of Economic Perspectives, 2015, 29(4), pp. 227-244.

[3] EVANS, Ch., JACKSON, O.; RYDEN, G. Baltic iron and the British iron industry in the eighteenth century. The Economic History Review, 2002, 55(4), pp. 642-665.

[4] HYDE, Ch.K. Technological change and the British iron industry, 1700-1870. Princeton, Princeton University Press, 2019.

[5] ROKICKI T., MICHALSKI K., RATAJCZAK M., SZCZEPANIUK H., GOLONKO M.,: Wykorzystanie odnawialnych źródeł energii w krajach Unii Europejskiej, Rocznik Ochrona Środowiska, 2018, 20, s. 1318-1334.

[6] ALLEN, R.C. International competition in iron and steel, 1850-1913. The Journal of Economic History, 1979. 39(4), pp. 911-937. 
[7] ALDCROFT, D.H. The Entrepreneur and the British Economy, 1870 - 1914 1. The Economic History Review, 1964, 17(1), pp. 113-134.

[8] BURN, D.L. The economic history of steelmaking, 1867-1939: a study in competition. Cambridge, University Press, 1940.

[9] BURNHAM, T. H., HOSKIN, G.O. Iron and Steel in Britain, 1870-1930, London, Allen and Unwin, 1943.

[10] MÜLLER, D.B., WANG, T., DUVAL, B., GRAEDEL, T.E. Exploring the engine of anthropogenic iron cycles. Proceedings of the National Academy of Sciences, 2006, 103(44), PP. 16111-16116.

[11] IRWIN, D.A. Explaining America's surge in manufactured exports, 1880-1913. Review of Economics and Statistics, 2003, 85(2), pp. 364-376.

[12] YELLISHETTY, M.; RANJITH, P.G.; THARUMARAJAH, A. Iron ore and steel production trends and material flows in the world: Is this really sustainable? Resources, conservation and recycling, 2010, 54(12), pp. 1084-1094.

[13] BARAN, J., ROKICKI, T. Productivity and efficiency of US metal industry in 2006-2014. In Metal 2015: 24th International Conference on Metallurgy and Materials. Conference Proceedings. Ostrava: TANGER, 2015, pp. 1841-1846.

[14] PAULIUK, S., WANG, T., MULLER, D.B. Steel all over the world: Estimating in-use stocks of iron for 200 countries. Resources, Conservation and Recycling, 2013, 71, pp. 22-30.

[15] HATAYAMA, H., DAIGO, I., MATSUNO, Y., Adachi, Y. Outlook of the world steel cycle based on the stock and flow dynamics. Environmental science \& technology, 2010, 44.16: 6457-6463.

[16] YELLISHETTY, M., MUDD, G.M. Substance flow analysis of steel and long term sustainability of iron ore resources in Australia, Brazil, China and India. Journal of cleaner production, 2014, 84, pp. 400-410.

[17] ROKICKI, T., BARAN, J. Situation of steel industry in Poland. In Metal 2015: 24th International Conference on Metallurgy and Materials. Conference Proceedings. Ostrava: TANGER, 2015, pp. 2044-2049.

[18] BLASCHKE, W., WITKOWSKA-KITA, B., BIEL, K. Analiza możliwości pozyskiwania krytycznych surowców mineralnych. Rocznik Ochrony Środowiska, 2015, 17, 1, pp. 792-813.

[19] BLASCHKE, W., WITKOWSKA-KITA, B., BIEL, K. Analiza możliwości pozyskiwania strategicznych surowców mineralnych. Rocznik Ochrona Środowiska, 2015, 17, 2, pp. 1428-1448.

[20] HELLMER, S., EKSTRAND, J. The iron ore world market in the early twenty-first century - the impact of the increasing Chinese dominance. Mineral Economics, 2013, 25(2-3), pp. 89-95.

[21] Eurostat Database, [viewed 2019-03-20]. Available from: https://ec.europa.eu/eurostat/data/database.

[22] World Steel Association, [viewed 2019-03-20]. Available from: https://www.worldsteel.org/steel-bytopic/statistics/steel-statistical-yearbook.html.

[23] World Bank Open Data, [viewed 2019-03-20]. Available from: https://data.worldbank.org/.

[24] REBIASZ, B. Polish Steel Consumption 1974-2008, Resources Policy, 31, 2006, pp. 37-49.

[25] KWANG-SOOK, H. Steel Consumption and Economic Growth in Korea: Long-Term and ShortTerm Evidence, Resources Policy, 36, 2011, pp. 107-113.

[26] DAHLSTROM, K.; EKINS, P. Combining economic and environmental dimensions: Value chain analysis of UK iron and steel flows. Ecological Economics, 2006, 58(3), pp: 507-519.

[27] WANG, T., MULLER, D.B., GRAEDEL, T.E. Forging the anthropogenic iron cycle. Environmental science \& technology, 2007, 41(14), pp. 5120-5129.

[28] SPATARI, S., BERTRAM, M., FUSE, K., GRAEDEL, T.E., SHELOV, E. The contemporary European zinc cycle: 1-year stocks and flows. Resources, Conservation and Recycling, 2003, 39(2), pp. 137-160.

[29] SPATARI, S., BERTRAM, M., FUSE, K., GRAEDEL, T.E., RECHBERGER, H. The contemporary European copper cycle: 1 year stocks and flows. Ecological Economics, 2002, 42(1-2), pp. 27-42.

[30] ROKICKI, T., Situation of steel industry in European Union. In METAL 2016: 25th Anniversary International Conference on Metallurgy and Materials. Ostrava: TANGER, 2016, pp. 1981-1986. 